\title{
Customers' Opinions on Reasons for Using Online Banking: Experience of Customers in Tanzania
}

\author{
Richard Sikira \\ The Institute of Accountancy Arusha
}

\begin{abstract}
Information technology has revolutionalised the banking industry with enormous benefits. However, there have been mixed perceptions on preferring online banking to traditional banking. These perceptions usually change over time because of deliberate efforts done by stakeholders. This study aimed to determine the opinions of customers on the reasons for using online banking services. In conducting this research, the study opted to use a case study research design. The study employed 60 CRDB Bank customers as its sample size. The study collected its data through primary data, by using a semi-structured questionnaire that allowed the collection of quantitative and qualitative data. The researcher employed content analysis through descriptions for qualitative data and simple descriptive statistics analysis through frequencies and percentages for quantitative data. The study found that most respondents (customers) use online banking because it saves time, offers instant feedback, is reliable, and is secure and convenient. The study recommends more awareness and understanding of online banking services to users to enjoy the enormous benefits of online banking services. Furthermore, customer support must be improved and ensure keeping promises related to solving customers' problems. The study recommends categorically further research on the contribution of mobile money to the reduction of income poverty.
\end{abstract}

\subsection{Introduction}

Banks under the aspiration to consolidate their competitiveness in the market have been forced to introduce alternative service delivery channels to influence and retain customers. This aspiration made banks design various products that, in addition to the one provided in a traditional banking style, are now using the online platform to facilitate transactions online with ease and convenience. Many financial institutions around the globe, whether small or big, are using online banking systems. As a result, the effort to opt for online banking has contributed to the improved quality and customer service, reduced business costs, and the concentration on essential banking services (Lee, 2009; Selvanathan et al., 2016).

Online banking and internet banking are familiar words used synonymously to describe the financial transactions conducted by a customer using a device over the internet (Akhter, 2015). Additionally, it is a system that helps customers access bank products and services and interact with their general information by using their computers or other devices such as mobile phones (Brun et al., 2016; Dhurup et al., 2014c). One of the significant conditions for online banking to serve customers is the availability of the internet. Online banking through the internet offers services such as checking balance, viewing some personal details, paying bills to various vendors, money transfer, paying loans, and procuring financial instruments and certificates of deposit (De Oliveira Santini et al., 2018; Kazi, 2015; Zabri et al., 2018).

Apart from the enormous dangers of applying online technology as the world heading toward a fully techno globalised world, financial institutions are still exploring, adapting, and strengthening themselves in online banking without hesitation (Hernández-Murillo et al., 2010; Sha \& Mohammed, 2017). This bold decision to cling to technology despite the encroached risks is motivated by the fact that applying online banking is beneficial to financial institutions than the risks perceived (Ahmed et al., 2017; Halili, 2014). One of the advantages is the comfort and convenience of doing business in which both service providers and the 
customers are enjoying it. Moreover, there are no time limitations when banks are closed, and even if it is weekends, still services are available. Furthermore, the geographical barriers are no longer reasons for providing a quality service and reduced costs for both the service provider and customers (Fox, 2014; Loureiro et al., 2014). Tracing the historical trends of online banking used commonly nowadays by many financial institutions has its roots way back in the 1990s in the United States of America that was the first to introduce these online services (Chan \& Lu, 2004). Later on, other countries embarked on adopting that technology in their various banking services, including the United Kingdom, India, China, and the rest of all countries in the globe (Sohail \& Shanmugham, 2003). It is, therefore, correct to conclude that it is difficult to trace a country in the world whose financial institutions do not use online banking, whether it is a developing or a developed country (Fox, 2014).

In Tanzania, the history of the banking industry is in three categories (Lwiza \& Nwankwo, 2002). The first category is the colonial era, this period spans from the times of German rule in the then Tanganyika in 1905 when the German bank known as Deutsch-Ostafrikanische Bank set a branch in Tanganyika. The bank also served Rwanda and Burundi, which were parts of Tanganyika. After the German colonial rule ended, the British came in. During the early 1950s, several foreign banks were operating in Tanganyika, such as the Ottoman Bank, Bank of India, Bank of Baroda, Commercial Bank of Africa, and the National Bank of Pakistan.

Another period is the socialist era, which had the features of economic monopolisation. This period started after the endorsement of the Arusha Declaration in 1967. At that time, all the banks were monopolised and put under government ownership. The last period is the economic liberalisation era which started around the 1990s, whereby several economic reforms began to strike Tanzania, including the banking and monetary sector. The banking reforms were suggested by the Nyirabu Commission to improve and develop the banking sector (Binamungu \& Ngwilimi, 2006).

After the period of reforms in the banking sector, the age of information technology development and Tanzania entered into that wave, just like many other countries. In reality, the significant ICT development in the banking sector began to take shape through electronic banking and its related services in the early 2000s (Erick, 2015). At that period, many banks began introducing several online services for their customers, such as establishing an automatic teller machine (ATM) and issuing ATM cards, which were sometimes enhanced with several online services through VISA and Master card. Technological advancement and business competition are the reasons for most banks in Tanzania to invest heavily in ICT. The aim is to improve their services for customers through linking their services with mobile companies, as many people in Tanzania prefer mobile phone services.

CRDB Bank Plc is among the largest banks in Tanzania, a publicly owned commercial bank headquartered in Dar Es Salaam, Tanzania. The bank operates three principal subsidiaries, namely CRDB Bank Burundi, a wholly-owned affiliate based in Bujumbura in the Republic of Burundi. Another one is CRDB Insurance Broker Limited, a leading Insurance broker service provider operating in Tanzania and CRDB Microfinance Services Limited. The bank has been in operation for about 24 years and currently has a total capital of TZS 873 billion, and the total assets were valued at TZS 6.6 trillion. CRDB has over 3400 staff who offer services to over 3.3 million customers in 268 branches at 560 ATMs with the support of 14,761 bank agents and 2,237 merchant point of sales. The bank has abroad set of online banking services, commonly known as CRDB internet banking, allowing customers to easily access their bank account information and perform various transactions securely and conveniently. This service has unique features such as enabling customers to conduct bulk payments, fund transfers, multi-currency transfer, paying bills to different service providers, and paying bills through mobile payments (CRDB, 2019).

Since the introduction of online banking services in Tanzania in the early 2000s, CRDB was among the pioneers to launch such services, and it is over 20 years now. For a long time, Tanzanian customers were reluctant to use online banking services, and banks almost influenced customers to adopt the technology (Robert, 2011). The bank since then took many initiatives to improve online banking services. Therefore, it is essential to explore the current perception of customers of CRDB Bank regarding online banking services.

\subsection{Literature Review}


Online banking has contributed massively to the modernisation of banking services which has transformed from a traditional banking channel to a digital channel. Online banking services such as balance enquiry, printing statements, fund transfers to other accounts and bill payments are becoming famous nowadays (Fo \& Ak, 2015).

The study conducted by Islam et al. (2019b) in Bangladesh on electronic banking found that banking, like other sectors, has passed through many transformations from traditional banking to online banking. The main reason is the competitive business environment, which requires a business to be innovative to serve customers. Similarly, customers are forced by the same technological advancement to use new banking styles introduced by banks.

The customers' perception of online banking is the cornerstone for making assessments regarding reasons for using online banking services, as supported by Aribake (2015), who conducted a study on online banking in Nigeria. Throughout the study, it was established that customers set their reasons for using online banking due to perceived benefits that are enjoyed when a person uses online banking services. The reasons established by customers are convenience and flexibility towards accessing their bank accounts from anywhere at any time compared to traditional banking.

The issue of convenience is supported by the fact that customers perceive online banking services as a one-stop centre for over $90 \%$ of shopping needs, fund transfer and bill payment. Customers are no longer limited by geographical location and time to perform their transactions. This has been supported by other studies on ebanking and customer satisfaction which found that customers use online banking services because they provide an option for performing the transaction in a click of a minute at the customer's comfort zone (Kiunsi, 2013; Muluka, 2015).

Furthermore, customers choose to use online banking due to cost issues such as transport costs, costs associated with bank charges. Kiunsi (2013) elaborated that bank rates in online banking are between 5\% to $3.40 \%$ annually, which is comparatively cheaper.

On transport costs, as established by Erick (2015) in a study on perceptions of customers on e-banking, customers perceive that using online banking is cheaper than physical branches. The cost of transport associated with time is a vital factor for consideration. Those customers living in big cities, travelling from one point to another is a challenge. These customers prefer to use online banking as it saves transport costs and time.

Muluka (2015) conducted a study on digital banking and customer satisfaction in Bungoma, Kenya, which found that the customer uses online banking services because the services are speedy. Traditionally, going to a bank for transaction purpose may take a minimum of half an hour, but at maximum, even a single day can be lost for that purpose. A customer on a lot to do with his list can perform many transactions precisely and in a short time, hence spend the rest of time in productive activities.

A study by Erick (2015) on customer perceptions on e-banking in Tanzania provides a bundle of reasons why customers in Tanzania use online banking services, and it keeps on becoming prominent. The reasons in this study were the following; First, it is saving the travel cost to the bank, saving the travelling and processing time, instant feedback from the system on transaction confirmation, and customer service. Saving time is an essential factor that influences the customers' preference to use online banking. The above finding is similar to the study conducted by Mchomba (2018) on the impacts of electronic banking on customer satisfaction in the Tanzania Banking Industry and found the same.

A study conducted by Effah and Nartey (2016) in Ghana on customer satisfaction on online banking found that online banking adds customer satisfaction. Thus, when a customer is presented with the benefits of online banking and referred by a close person, then a decision to use it is always guaranteed.

\subsection{Methodology}

This study conducted in the CRDB Bank Azikiwe branch in Dar Es Salaam employed a case study research design to execute the research. Based on the nature of this study which intends to examine customers' perceptions, the case study is very suitable as it enables in-depth study of the matter (Kothari, 2004). The study population were CRDB bank customers, who made a sample size of 60 online banking customers whose number reached after saturation. The sample was approached through non - probability sampling 
techniques known as purposive sampling, whose focus was to approach respondents known to possess essential information for the study. The study employed primary data gathered by semi-structured questionnaire with open and closed questions where qualitative and quantitative data were collected. The study employed content analysis for qualitative data and simple descriptive statistics for quantitative data through frequency and percentages in data analysis.

\section{Findings}

Table 1.0: Reasons for Using Online Banking

$\mathrm{N}=60$

\begin{tabular}{|l|l|c|c|c|l|c|c|}
\hline S/N & \multicolumn{1}{|c|}{ Reasons for Using Online Banking } & Agree & $\%$ & Neutral & $\%$ & Disagree & $\%$ \\
\hline $\mathbf{1}$ & It provides instant feedback & 53 & 88 & 4 & 7 & 3 & 5 \\
\hline 2 & It saves time & 50 & 83 & 3 & 5 & 7 & 12 \\
\hline 3 & It is convenient & 46 & 77 & 8 & 13 & 6 & 10 \\
\hline 4 & It is reliable & 42 & 70 & 8 & 13 & 10 & 17 \\
\hline 5 & $\begin{array}{l}\text { It is easy to deposit and withdraw } \\
\text { money }\end{array}$ & 38 & 63 & 12 & 20 & 10 & 17 \\
\hline 6 & It is secure & 38 & 63 & 13 & 22 & 9 & 15 \\
\hline 7 & It is cheaper & 31 & 52 & 8 & 13 & 21 & 35 \\
\hline
\end{tabular}

Source: Research Findings (2020)

\subsection{Security of Online Banking in Making Financial Transactions}

The results on customers' opinions on the reasons for using online banking services provide a positive insight that online banking is secure in making financial transactions, as presented in Table 1.0. Results from the field show that most respondents, who were $38(63 \%)$ of all respondents, agreed that online banking is secure in making financial transactions. Apart from the previous respondents who agreed with the statement, 13 respondents, who make $22 \%$ of all respondents, were neutral on whether online banking is secure in making financial transactions. Lastly, 9 respondents (15\%) disagreed with this statement that online banking is secure in making financial transactions.

Furthermore, the study explored reasons as to why the majority of respondents think online banking is secure. One respondent said, 'I believe online banking is secure because I do not have a bad experience using it.' Another respondent provided that 'The online banking security is improving every day. Therefore, apart from minor challenges on online banking security but I assert that online banking is secure in the general context as there are very few cases of online banking theft' The study in this regard found that many customers do not have a bad experience with an online bank. They said that their money reached the intended destinations without problems. As a result of the little experience of security challenges, they opinioned that online banking is secure for their various transactions.

\subsection{Reliability of Using Online Banking}

The study was interested in knowing customers' opinions on reasons for using online banking services by explicitly examining the issue of reliability. In this regard, most respondents, as per field data, suggested clearly that online banking is reliable. Expressly, the field results indicated that most of the respondents, 42 (70\%), agreed that online banking is reliable. Additionally, $8(13 \%)$ respondents were neutral about the statement on the reliability of online banking services; hence their position is not clear. On the other side, 10 respondents, who reflect $17 \%$ of all respondents, disagreed that online banking is reliable.

Additionally, respondents through semi-structured questions provide qualitative data in the form of descriptions regarding how they feel the reliability of online banking. The respondents provided that 'We feel online banking is reliable because any time in 24/7 whenever we want to send money via mobile phone, internet banking and ATM, the services are available.' They asserted that they are informed earlier in case of any inconvenience, so they get prepared; thus, they feel online banking is a dependable service. 


\subsection{Time-saving of Online Banking}

In this sub-variable, respondents in the field were requested to indicate their opinions as customers on reasons for using online banking services, tracing the time-saving as the reason for using online banking. Online banking was noted to save time, as an opinion by most of the respondents in the field. Expressly, the field results indicated that most of the respondents, 50 (83\%), agreed that online banking saves time. Additionally, 3 (5\%) of the respondents were neutral on whether online banking saves time or not. In another category, 7 (12\%) of the respondents disagreed that online banking saves time.

In this study, the respondents provided further details regarding how online banking saves time when used by customers. Based on their experience before introducing online banking, some respondents provided that 'Before introducing online banking, it took the whole day for performing transactions due to long queues in the banks. However, in the presence of online banking, a customer is just using the internet, mobile phone and or computer to complete transactions just in a couple offew minutes, and the transaction becomes successful.'

\subsection{The Convenience of Online Banking}

Respondents in the field were requested to indicate their opinions on the reasons for using online banking services. According to most respondents, as shown in the field data suggested that online banking is convenient to customers. Therefore, results from the field indicated that most of the respondents, who are 46 (77\%) of all respondents, agreed that online banking is convenient because most of the customers prefer to use it. Furthermore, $8(13 \%)$ of the respondents were neutral on whether online banking is convenient or not. However, $6(10 \%)$ of the respondents disagreed that online banking is convenient.

Throughout the study, it is established that among significant reasons for customers to use online banking services is convenience, as evidenced by data from the field. The reasons established by customers are such as convenience is based on flexibility towards accessing their bank account from anywhere at any time compared to traditional banking. Customers confirmed that 'There are no barriers to access the bank accounts regarding locations and thus it is not necessary to travel with hard cash as a customer can get money and use it regardless of the location.' Additionally, one respondent provided that 'I feel the online banking is convenient even when I travel abroad, whereas, through the VISA and Mastercard, I access my money even beyond the country borders'.

\subsection{The Cheapness of Online Banking Compared to Other Forms of Banking}

The study was interested to know the opinions of customers on reasons for using online banking services. Online banking is cheaper than other forms of banking, was the opinion suggested by most of the respondents in the field. Results from the field indicated that most of the respondents, 31 (52\%), agreed that online banking is cheaper than other forms of banking. Also, there were $8(13 \%)$ of respondents whose opinions were neutral regarding the cheapness of online banking services. In this study, some respondents disagreed and against the statement that online banking is cheaper than traditional banking. Those respondents stand at 21 $(35 \%)$ of all the respondents in the study.

Based on the above findings, respondents elaborated why they think online banking is cheaper than traditional banking. One respondent commented that 'If a person wants to conduct transactions, he/she has to set apart a bus fare or put fuel in a vehicle. As long as he/she is going to spend over 5 hours, then a budget for food has to be aside. Not only this but also the cost of time lost during this hassle is expensive as well.' All these costs can be avoided when a person uses online banking; hence customers perceive online banking as cheaper.

\subsection{Ease of Withdrawing and Depositing Money Online}

The researcher in this study intended to inquire respondents in the field to indicate their opinions on reasons for using online banking services. Therefore, it was opinioned that withdrawing and depositing money online was an easy thing for customers, as suggested by most of the respondents in the field. Results from the field 
indicated that most of the respondents, 38 (63\%) of all respondents, agreed that it is easy to withdraw and deposit money online, so most customers prefer to use it. Additionally, the study found that 12 (20\%) of the respondents were neutral on whether it is easy to withdraw and deposit money online or not. Lastly, 10 (17\%) of the respondents disagreed that it is easy to withdraw and deposit money online.

Respondents clarified furthermore that withdrawing and depositing money online is generally straightforward. In this regard, one respondent categorically asserted that 'I agree on ease of withdrawing and depositing money through ATM and even through mobile banking agents' However, other respondents explained that they never tried direct depositing money on ATMs capable of doing so. For those respondents who tried it, they confirmed that it is easy.

\subsection{Instant Feedback Offered by Online Banking}

In this sub-variable, respondents in the field were requested to indicate the customers' opinions on reasons for using online banking services. Online banking gives feedback instantly was the opinion suggested by most of the respondents in the field. Results from the field indicated that most of the respondents, 53 (88\%), strongly agreed that online banking gives feedback instantly. There were also neutral respondents who were 4 (7\%), and 3 respondents equal to $5 \%$ who disagreed with the statement on instant feedback regarding online banking.

Respondents affirmed that they get instant feedback when using online banking. Some respondents highlighted that 'It only takes one to three seconds to get feedback on any transaction online with a message of success or failure.'

\subsection{Discussion}

\subsection{Security of Online Banking in Making Financial Transactions}

In this study, respondents provided their opinions that they use online banking service because it is secure. Specifically, the results from the field show that the majority of 38 respondents, being $63 \%$ of all respondents, agreed that online banking is secure in making financial transactions, and thus it is a reason for them to use online banking.

Furthermore, the study explored the reasons as to why the majority of respondents think online banking is secure. The study in this regard found that many customers do not have a bad experience with online banking. They said that their money reached the intended destinations without problems. As a result of the little experience of security challenges, they opinioned that online banking is secure for their various transactions.

The findings concur with the study done by De Oliveira Santini et al. (2018), which revealed that online banking has enough security to be preferred by many customers. The level of security is noted through the internet offering services such as checking balance, viewing some personal details, paying bills to various vendors, money transfer and paying loans which have been noted to be secure (Kazi, 2015; Zabri et al., 2018).

Another study by Brun et al. (2016) and Dhurup et al. (2014c) suggested that online banking, despite its early challenges of insecurity in the early 90s and 2000s, has been strengthened over the recent years with higher levels of security.

In general, as presented above, the findings suggest that online banking is secure in making financial transactions because in most cases, money sent via online banking reaches the destination, and it is not very easy to tamper with the system.

The results imply that significant changes and enhancements are being made to online banking security by governments, financial institutions, telecommunications companies, and information and security firms. This increased the level of online banking protection so that it is not easy to exploit it. Stuff such as surveillance cameras in ATMs, mobile banking password levels, regular customer information monitoring, real-time input on a transaction's success or failure, and many other related issues improves online banking services.

\subsection{Reliability of Using Online Banking}

The study was interested to know the opinions of customers on reasons for using online banking services by 
explicitly examining the issue of reliability. In this regard, the majority of respondents per field data suggested clearly that online banking is reliable. Expressly, the results from the field indicated that the majority of the respondents, $42(70 \%)$, agreed that online banking is reliable.

The respondents provided that 'We feel online banking is reliable because any time in 24/7 whenever they want to send money via mobile phone, internet banking and ATM, the services are available.' They asserted that they are informed earlier in case of any inconvenience, so they get prepared; thus, they feel online banking is a dependable service.

Concerning the above findings, Kazi (2015) revealed the reliability of online banking services, which is reflected through prompt responses, attentiveness, and ease of use, had a considerable impact on customers who perceived it dependable and thus satisfied by using it.

The findings from the field and the above literature conclude that the reliability of online banking is an essential factor for customers. Many customers perceive online banking to be reliable, so it becomes widespread, integrated, and preferred by many customers and financial institutions.

The results imply that online banking service providers and their partners have done their best to minimise the obstacles experienced in previous times regarding online banking. These challenges are service interruptions and technical difficulties that have long resulted in the absence of service.

\subsection{Time-Saving of Online Banking}

Online banking was noted to save time, as an opinion by most of the respondents in the field. Expressly, the results from the field indicated that the majority of the respondents, $50(83 \%)$, agreed that online banking saves time.

In this study, the respondents provided further details regarding how online banking saves time when used by customers. Based on their experience before introducing online banking, some respondents provided that 'Before introducing online banking, it took a whole day for performing transactions due to long queues in the banks. However, in the presence of online banking, a customer is just using the internet, mobile phone and or computer to complete transactions just in a couple offew minutes, and the transaction becomes successful.'

A study by Erick (2015) on customer perceptions on e-banking in Tanzania provides a bundle of reasons why customers in Tanzania use online banking services, and it keeps on becoming prominent. The reasons in this study were the following; First, it is saving the travel cost to the bank, saving the travelling and processing time, instant feedback from the system on transaction confirmation, and customer service. Saving time is an essential factor that influences the customers to prefer to use online banking. The above finding is similar to the study conducted by Mchomba (2018) on the impacts of electronic banking on customer satisfaction in the Tanzania Banking Industry and found the same.

The results in this section confirm, as presented above that online banking saves time for customers. This means growing productivity on the customer side as other efficient works are now used for the entire day that would have been spent on going to the bank, getting into a long queue, and waiting to be served.

\subsection{The Convenience of Online Banking}

Respondents in the field were requested to indicate their opinions on the reasons for using online banking services. In this regard, according to the majority of respondents, as shown in the field data suggested that online banking is convenient to customers. Therefore, results from the field indicated that most of the respondents, who are $46(77 \%)$ of all respondents, agreed that online banking is convenient, so most of the customers prefer to use it.

Throughout the study, it is established that among significant reasons for customers to use online banking services is convenience, as evidenced by data from the field. The reasons established by customers are such as convenience is based on flexibility towards accessing their bank account from anywhere at any time compared to traditional banking. Customers confirmed that 'There are no barriers to access the bank accounts regarding locations and thus it is not necessary to travel with hard cash as a customer can get money and use it regardless of the location.' Additionally, one respondent provided that 'I feel the online banking is convenient even when I travel abroad, whereas, through the VISA and Mastercard, I access my money even beyond the country borders'. 
The issue of convenience is supported by the fact that customers perceive online banking services as a onestop centre for over $90 \%$ of shopping needs, fund transfers, and bill payments. Customers are no longer limited by geographical location and time to perform their transactions. This has been supported by other studies on e-banking and customer satisfaction which found that customers use online banking because it provides an option for performing the transaction in a click of a minute at the customer's comfort (Kiunsi, 2013; Muluka, 2015).

E-banking provides a higher degree of convenience that enables customers to access internet banking at all times and places. Apart from that, the ease of access to computers is perceived as a measure of relative advantage. Chowdhury et al. (2017); Farrell, Greig \& Hamoudi (2019); Sarjiyus, Oye \& Baha (2019) revealed that some service quality determinants are predominantly satisfiers and others that are predominantly dissatisfiers with the primary sources of satisfaction being attentiveness, responsiveness, care and friendliness. The primary sources of dissatisfaction are integrity, reliability, responsiveness, availability and functionality. The results imply that clients like the ease of improving access to their money without obstacles such as geographical factors. Besides, the results imply that as technology grows, it becomes used by financial institutions to add more consumer choices.

\subsection{The Cheapness of Online Banking Compared to Other Forms of Banking}

The study was interested to know the opinions of customers on the reasons for using online banking services. Online banking is cheaper than other forms of banking, was the opinion suggested by most of the respondents in the field. Results from the field indicated that the majority of the respondents, 31 (52\%) of the respondents, agreed that online banking is cheaper than other forms of banking, hence being a reason for using it.

Based on the above findings, respondents elaborated why they think online banking is cheaper than traditional banking. One respondent commented that 'If a person wants to conduct transactions, he/she has to set apart a bus fare or put fuel in a vehicle. As long as he/she is going to spend over 5 hours, then a budget for food has to be aside. Not only this but also the cost of time lost during this hassle is expensive as well.' All these costs can be avoided when a person uses online banking; hence customers perceive online banking to be cheaper.

The above finding is similar to the study conducted by Malik et al. (2019); whereas most online banking customers consider it cheaper, their behaviour to adopt the online services is determined by this factor and other benefits of using online banking.

As per the findings from respondents and literature review, it can be concluded that online banking services are cheaper compared to traditional banking, whereas a customer does not spend extra costs such as transport to go to the bank as the transaction can be done at home or wherever he or she is located.

The results presented above imply that customers save a certain amount of money compared to conventional banking when using the online mobile bank. It also means that the money saved will help other needs for livelihood, so it can be argued that online banking improves people's livelihood.

\subsection{Ease of Withdrawing and Depositing Money Online}

The researcher in this study intended to inquire respondents in the field to indicate their opinions on reasons for using online banking services. Therefore, it was opinioned that withdrawing and depositing money online was an easy thing for customers, as suggested by most of the respondents in the field. Results from the field indicated that the majority of the respondents, $38(63 \%)$ of the respondents, agree that it is easy to withdraw and deposit money online, so most customers prefer to use it.

Respondents clarified furthermore that withdrawing and depositing money online is generally straightforward. In this regard, one respondent categorically asserted that 'I agree on the ease of withdrawing and depositing money through ATM and even through mobile banking agents' However, other respondents explained that they never tried direct depositing money on ATMs capable of doing so. For those respondents who tried it, they confirmed that it is easy.

Kiunsi (2013) confirmed that using online banking services is easy and that online banking customers in Tanzania draw and deposit their money through online bank outlets and vendors spread across the country. Generally, as per the findings of the study and the literature, it is revealed that the withdraw and depositing of 
money online is easy; that is one of the reasons why customers prefer such services.

This finding suggests that it is easy to deposit and withdraw money online as long as a customer has primary education and can read and write. The process of withdrawing and depositing money online can also be practised by many individuals, which means fewer queues in banks.

\subsection{Instant Feedback Offered by Online Banking}

In this sub-variable, respondents in the field were requested to indicate the customers' opinions on reasons for using online banking services. Online banking gives feedback instantly was the opinion suggested by most of the respondents in the field. Results from the field indicated that the majority of the respondents, 53 (88\%), strongly agreed that online banking gives feedback instantly.

Respondents affirmed that they get instant feedback when using online banking. Some respondents highlighted that 'It only takes one to three seconds to get feedback on any transaction online with a message of success or failure.'

A study by Oertzen and Odekerken-Schröder (2019) and another study by Sivaraj et al. (2019) support the findings of this study, whereas they found that customers adopt and or continue to use online banking as they get their feedback instantly in a situation if an entry is wrongly inserted and a message to alert the user is given. Furthermore, if a transaction fails or succeed, the message comes to the customer instantly; thus, the customer feels the essence of feedback using online banking compared to traditional banking.

Based on the above findings from the study and literature, it is clear that customers' feedback is an essential part of online transactions. Furthermore, most respondents believe that while using online banking, a customer gets feedback instantly.

Instant feedback means transparency to a customer's transactions as a customer under- stands whether his/her money has been sent. It also means a sense of customer care that offers the customer service team an opportunity to directly provide their assistance in an online failure or problem.

\subsection{Conclusions}

It is concluded that online banking is secure in making financial transactions according to the customers' opinions in the study area, so many customers use it. Online banking has many advantages, such as saving time, and many respondents concurred with this fact, as noted in the collected data. Furthermore, online banking is regarded as convenient, as suggested by most respondents in the field. Throughout the study, it was established that customers set their reasons for using online banking due to the perceived benefits that are enjoyed when using online banking services.

\subsection{Recommendations}

To raise awareness and understanding of online - banking services. The bank should influence the usefulness, ease of use, and self-efficacy of online banking by giving customers information on the advantages of online banking. The bank may produce brochures that contain details of online -banking services, including usefulness and ease of use, and the bank may organise training courses in various online banking services. The bank should also continue to provide information and assistance on online banking using well-qualified and professional staff with good customer care through help desks situated in banking halls.

\subsection{Reference}

[1] Ahmed, R. R., Vveinhardt, J., Štreimikienè, D., Ashraf, M., \& Channar, Z. A. (2017). Modified SERVQUAL model and effects of customer attitude and technology on customer satisfaction in the banking industry: mediation, moderation, and conditional process analysis. Journal of Business Economics and Management, 18(5), 974-1004. https://doi.org/10.3846/16111699.2017.1368034

[2] Akhter, S. H. (2015). Impact of Internet Usage Comfort and Internet Technical Comfort on Online Shopping and Online Banking. Journal of International Consumer Marketing, 27(3). https://doi.org/10.1080/08961530.2014.994086

[3] Aribake, F. O. (2015). Impact of ICT tools for Combating Cyber Crime in Nigeria Online Banking: A conceptual Review. International Journal of Trade, Economics and Finance, 6(5), 272-277. https://doi.org/10.18178/ijtef.2015.6.5.481 
[4] Binamungu, C. S., \& Ngwilimi. G.S. (2006). Regulation of Banking Business in Tanzania.

[5] Brun, I., Rajaobelina, L., \& Ricard, L. (2016). Online Relationship Quality: Testing an Integrative and Comprehensive Model in the Banking Industry. Journal of Relationship Marketing, 15(4). https://doi.org/10.1080/15332667.2016.1242400

[6] Chan, S. C., \& Lu, M. (2004). Understanding internet banking adoption and use behaviour. A Hongkong Perspective: Journal of Global Information Management, 12(3), 21-25.

[7] Chowdhury, I.A., Othman, A.S., Bo, Y. \& Huey, L.Y., 2017, "Driving Force of E-Loyalty in Online Banking Sector in the Context of Malaysia," People: International Journal of Social Sciences, 3(3), 43-65.

[8] CRDB. (2019). Annual Report. Dar Es Salaam: CRDB.

[9] De Oliveira Santini, F., Ladeira, W. J., Sampaio, C. H., \& Perin, M. G. (2018). Online banking services: a meta-analytic review and assessment of the impact of antecedents and consequents on satisfaction. Journal of Financial Services Marketing, 23(3-4). https://doi.org/10.1057/s41264-018-0059-4

[10] Dhurup, M., Surujlal, J., \& Redda, E. (2014a). Customer perceptions of online banking service quality. Mediterranean Journal of Social Sciences, 5(2). https://doi.org/10.5901/mjss.2014.v5n2p587

[11] Dhurup, M., Surujlal, J., \& Redda, E. (2014c). Customer perceptions of online banking service quality. Mediterranean Journal of Social Sciences, 5(2), 587-594.https://doi.org/10.5901/mjss.2014.v5n2p587

[12] Effah, J., \& Nartey, M. (2016). Contextual effects on online banking implementation process and service content: A case study in Ghana. Journal of Internet Banking and Commerce, 21(2).

[13] Erick, C. (2015). Customer Perceptions on E-Banking in Tanzania: A Case of Selected Commercial Bank in Dar Es Salaam.

[14] Farrell, D., Greig, F. \& Hamoudi, A., 2019, "The Evolution of the Online Platform Economy: Evidence from Five Years of Banking Data," AEA Papers and Proceedings, 109, 362-366.

[15] Fo, O., \& Ak, A. (2015). Journal of Internet Banking and Commerce Factors Influencing Intention to Adopt Internet Banking by Postgraduate Students of the University of Ibadan, Nigeria. Journal of Internet Banking and Commerce (Vol. 20, Issue 3). http://www.icommercecentral.com

[16] Fox, D. (2014). Online Banking. Datenschutz Und Datensicherheit - DuD, 38(5). https://doi.org/10.1007/s11623-014-0122-9

[17] Halili, R. (2014). The impact of Online Banking on Bank Performance. Charles University in Prague.

[18] Hernández-Murillo, R., Llobet, G., \& Fuentes, R. (2010). Strategic online banking adoption. Journal of Banking and Finance, 34(7). https://doi.org/10.1016/j.jbankfin.2010.03.011

[19] Islam, S., Kabir, M. R., Dovash, R. H., Nafee, S. E., \& Saha, S. (2019b). Impact of Online Banking Adoption on Bank's Profitability: Evidence from Bangladesh. European Journal of Business and Management Research, 4(3). https://doi.org/10.24018/ejbmr.2019.4.3.38

[20] Kazi ZH, M. G. (2015). Factors that Influence the Adoption of Online Banking Services in Hyderabad. International Journal of Economics \& Management Sciences, 04(01). https://doi.org/10.4172/21626359.1000216

[21] Kiunsi, S. (2013). E-Banking and Customer Perception in Tanzanian Commercial Banks. Morogoro: Mzumbe University.

[22] Kothari, C. R. (2004). Research methodology: Methods and techniques (2nd ed.). New Age International (P), Ltd.

[23] Lee, M. C. (2009). Factors influencing the adoption of internet banking: An integration of TAM and TPB with perceived risk and perceived benefit. Electronic Commerce Research and Applications, 8(3). https://doi.org/10.1016/j.elerap.2008.11.006

[24] Loureiro, S. M. C., Kaufmann, H. R., \& Rabino, S. (2014). Intentions to use and recommend to others: An empirical study of online banking practices in Portugal and Austria. Online Information Review, 38(2). https://doi.org/10.1108/OIR-01-2012-0100

[25] Lwiza, R. B., \& Nwankwo, S. (2002). Market-driven transformation of the banking sector in Tanzania. International Journal of Bank Marketing, 20(1), 786-791.

[26] Malik, S., Nawaz, F., Shujahat, M., Kianto, A., Hussain, S., \& Ali, M. (2019). The determinants of the online banking adoption behavior by the theory of trying in developing countries: The case of Pakistani banks. Knowledge Management and E-Learning, 11(2), 247-261. https://doi.org/10.34105/j.kmel.2019.11.013

[27] Mchomba, D. (2018). The Impacts of Electronic Banking on Customer Satisfaction in Tanzania Banking Industry. Dar Es Salaam: Open University.

[28] Muluka, K. (2015). E-Banking and Customer's Perceptions in Tanzanian Commercial Banks. Nairobi Kenya: The University of Nairobi.

[29] Oertzen, A.S. \& Odekerken-Schröder, G., 2019, “Achieving continued usage in online banking: a postadoption study," International Journal of Bank Marketing, 37(6), 1394-1418.

[30] Robert, M. (2011). The Aspects of E-banking in Tanzania: New Phenomena. Dar Es Salaam - Tanzania. [31] Sarjiyus, O., Oye, N.D. \& Baha, B.Y., 2019, "Improved Online Security Framework for e-Banking Services 
in Nigeria: A Real-World Perspective," Journal of Scientific Research and Reports, 1-14.

[32] Selvanathan, M., Tan, P. J., Bow, T. F., \& Supramaniam, M. (2016). The Impact of Cost, Customer Experience, Ease of Use, and Trust towards Adoption of Online Banking. International Business Research, 9(11), 235. https://doi.org/10.5539/ibr.v9n11p235

[33] Sha, N., \& Mohammed, S. (2017). Virtual banking and online business. Banks and Bank Systems, 12(1), 7581. https://doi.org/10.21511/bbs.12(1).2017.09

[34] Sohail, M. S., \& Shanmugham, B. (2003). E-banking and customer preferences in Malaysia: an empirical investigation. Information Sciences, 150(3-4), 207-217.

[35] Zabri, S. M., Ahmad, K., \& Huay, H. H. (2018). Factors Influencing the Adoption of Online Banking Services in Malaysia. Advanced Science Letters, 24(5). https://doi.org/10.1166/asl.2018.113 